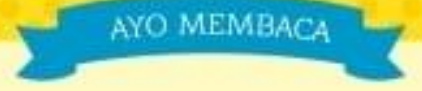

Dengan membaca, Kalsan menjacti sahabat orang-orang hebat.

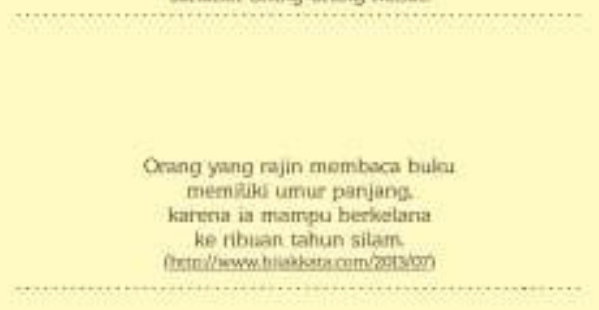

Sahabat baik bagkes adalah seseorang yand mengharliahiku buku yang belum pornah kuhaca. (Abraham Lincoln)

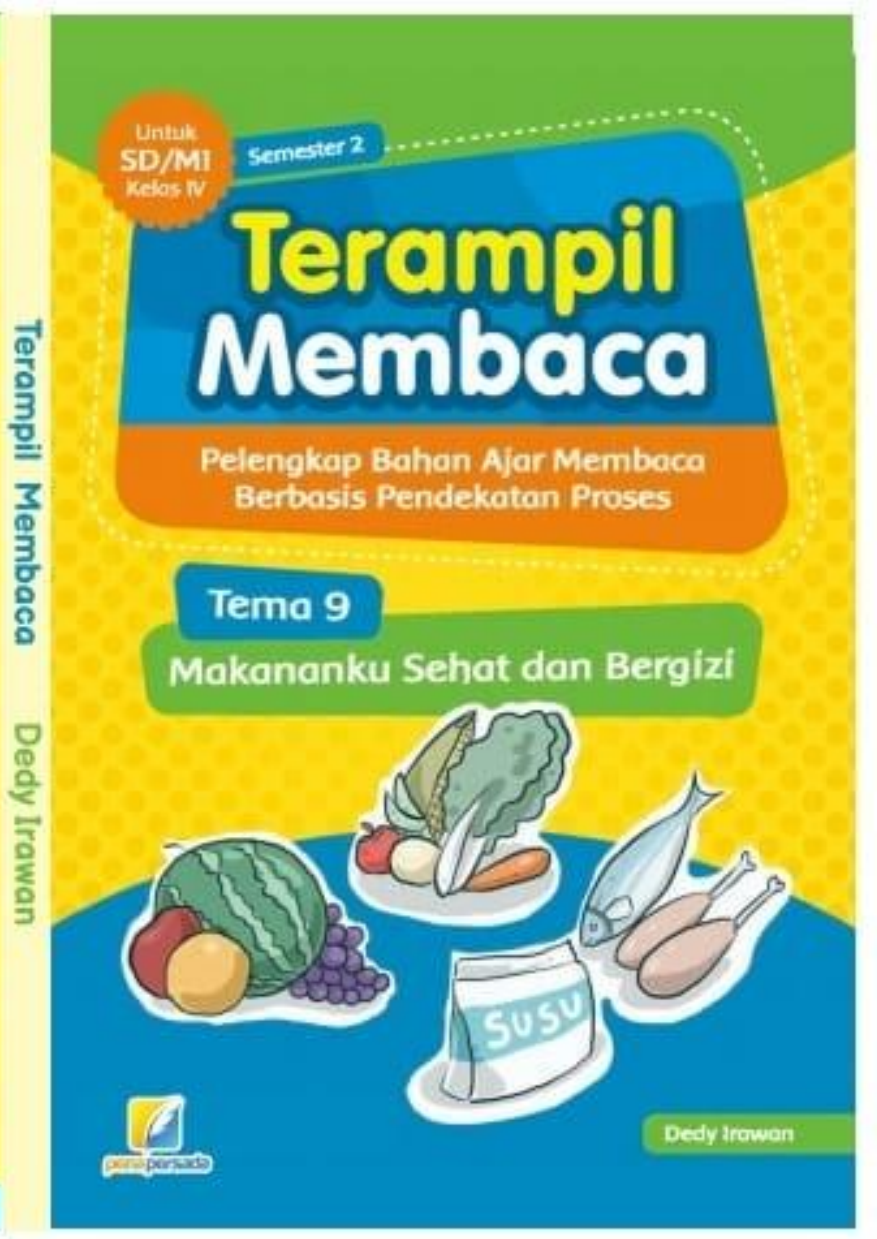




\section{TERAMPIL MEMBACA : \\ Pelengkap Bahan Ajar Membaca Berbasis Pendekatan Proses}

Dedy Irawan

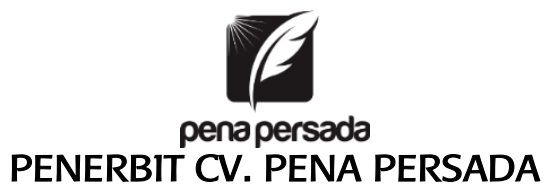




\section{TERAMPIL MEMBACA : Pelengkap Bahan Ajar Membaca Berbasís Pendekatan Proses}

Penulis:

Dedy Irawan

Editor :

Umar Abduloh

ISBN : 978-623-6837-55-9

Design Cover :

Bondan Widantoro

Layout :

Bondan Widantoro

Ilustrator :

Wigianto

Penerbit CV. Pena Persada

Redaksi :

Jl. Gerilya No. 292 Purwokerto Selatan, Kab. Banyumas Jawa Tengah

Email : penerbit.penapersada@gmail.com

Website : penapersada.com Phone : (0281) 7771388

Anggota IKAPI

All right reserved

Cetakan pertama : November 2020

Hak Cipta dilindungi oleh undang-undang. Dilarang memperbanyak karya tulis ini dalam bentuk apapun tanpa izin penerbit 


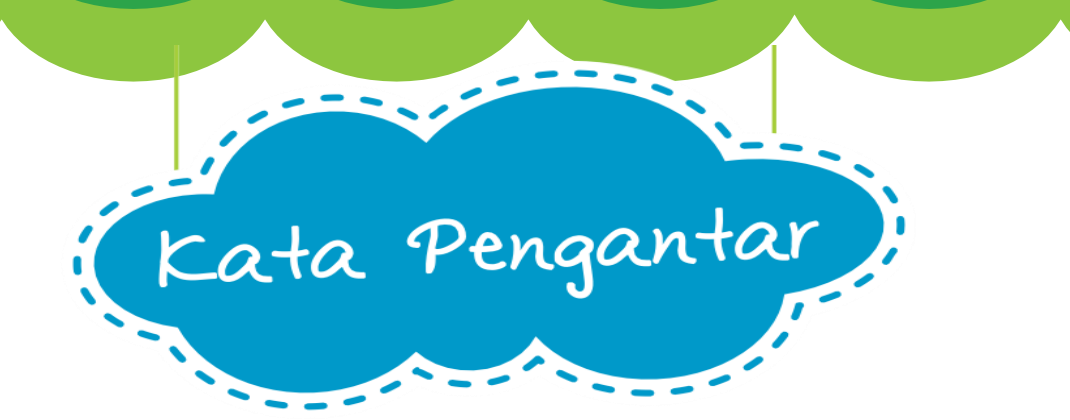

Puji syukur kami panjatkan kepada Tuhan Yang Maha Esa atas terselesaikannya buku Terampil Membaca: Pelengkap Bahan Ajar Membaca Berbasis Pendekatan Proses Tema 9 Makananku Sehat dan Bergizi untuk Kelas IV Semester 2 Sekolah Dasar Kurikulum 2013.

Buku ini dikembangkan sebagai bentuk perhatian yang besar terhadap upaya mengembangkan ilmu pengetahuan dan keterampilan berbahasa. Buku ini juga telah dikembangkan sesuai dengan pendekatan proses membaca. Pendekatan proses sangat penting dalam proses pembelajaran membaca yang meliputi lima langkah utama, yaitu: persiapan, membaca, menanggapi, memahami, dan meluaskan pemahaman (Tompkins \& Hoskison, 1995; Tompkins, 2010). Materi-materi yang disajikan dalam buku ini tidak hanya memberi pengetahuan secara teoretis, tetapi juga menekankan praktik dengan proses-proses tersebut.

Tema, subtema, dan pembelajaran yang disajikan dalam buku ini berdasarkan buku guru dan buku siswa tematik terpadu Kurikulum 2013 (Kemendikbud, 2014) dengan menerapkan teori pendekatan proses membaca. Buku ini disusun secara sistematis sesuai dengan standar dari BSNP.

Akhir kata, tiada gading yang tak retak, demikian pula dengan buku ini yang masih jauh dari sempurna. Kritik dan saran dari pembaca sangat diharapkan demi kesempurnaan buku ini.

Purwokerto,

Penulis 


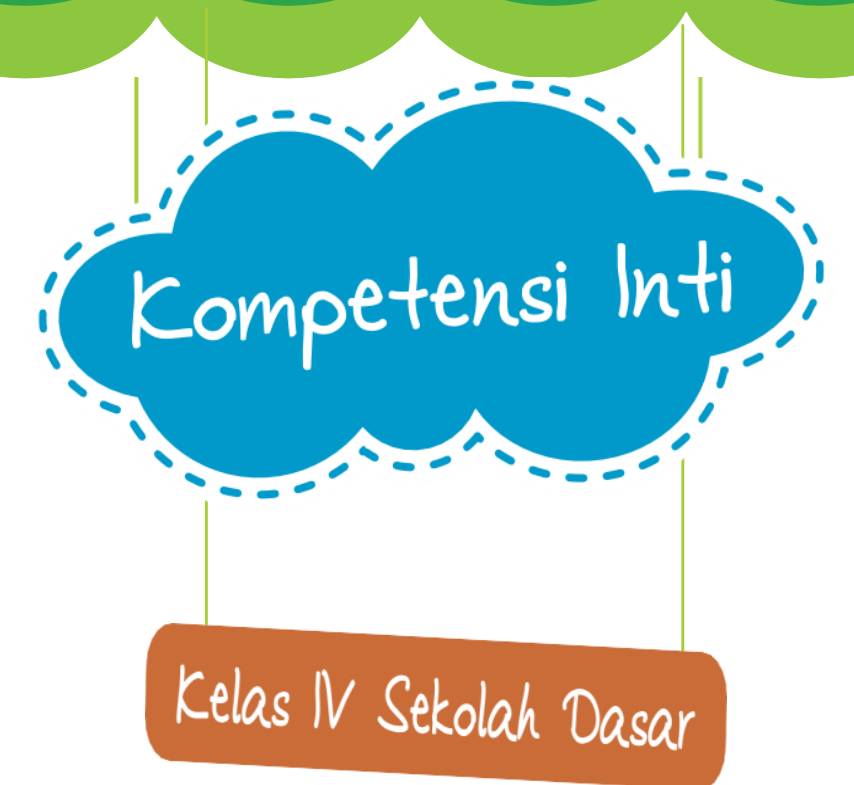

\begin{tabular}{|c|l|}
\hline Kompetensi & \multicolumn{1}{|c|}{ Deskripsi } \\
\hline Sikap & $\begin{array}{l}\text { Menerima, menjalankan, dan menghargai } \\
\text { ajaran agama yang dianutnya. }\end{array}$ \\
\hline Sikap Sosial & $\begin{array}{l}\text { Menunjukkan perilaku jujur, disiplin, santun, } \\
\text { percaya diri, peduli, dan bertanggung jawab } \\
\text { dalam berinteraksi dengan keluarga, teman, } \\
\text { guru, dan tetangga, dan negara. }\end{array}$ \\
\hline Pengetahuan & $\begin{array}{l}\text { Memahami pengetahuan faktual, konseptual, } \\
\text { prosedural, dan metakognitif pada tingkat } \\
\text { dasar dengan cara mengamati, menanya, dan } \\
\text { mencoba berdasarkan rasa ingin tahu tentamg } \\
\text { dirinya, makhluk ciptaan Tuhan dan } \\
\text { kegiatannya, dan benda-benda yang } \\
\text { dijumpainya di rumah, di sekolah, dan tempat } \\
\text { bermain. }\end{array}$ \\
\hline Keterampilan & $\begin{array}{l}\text { Menunjukkan keterampilan berfikir dan } \\
\text { bertindak kreatif, produktif, kritis, mandiri, } \\
\text { kolaboratif, dan komunikatif dalam bahasa } \\
\text { yang jelas, sistematis, logis dan kritis, dalam } \\
\text { karya yang estetis, dalam gerakan yang } \\
\text { mencerminkan anak sehat, dan tindakan yang } \\
\text { mencerminkan perilaku anak sesuai dengan } \\
\text { tahap perkembangannya. }\end{array}$ \\
\hline
\end{tabular}

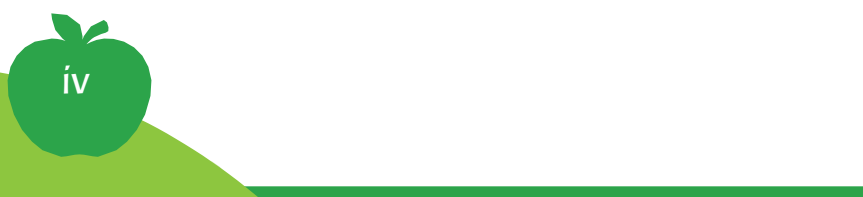





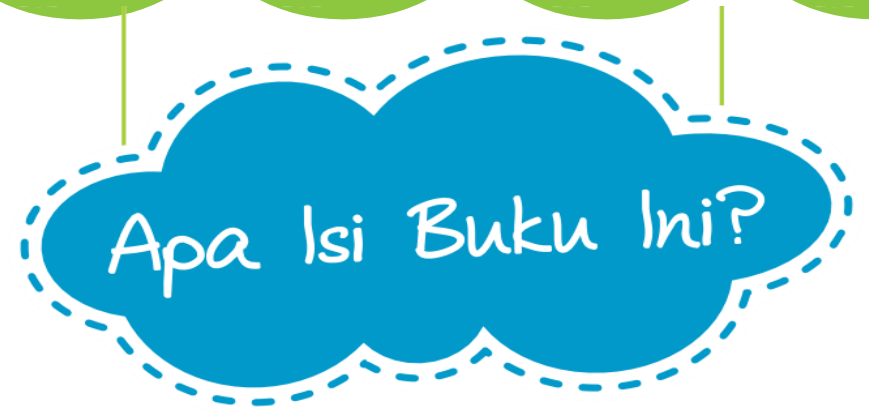

Anak-anak...Bagaima kabar kalian hari ini? Pasti sehat ya...

Buku yang kalian pegang ini adalah Buku Terampil Membaca. Di dalamnya terdapat materi pelajaran Bahasa Indonesia aspek keterampilan membaca Tema 9 "Makananku Sehat dan Bergizi". Kalian akan mempelajarinya secara khusus.

Buku ini berisi materi membaca yang diambil dari Buku Tematik Terpadu Kurikulum 2013 dan sumbersumber lainnya yang disusun berdasarkan pendekatan proses. Buku ini dapat dijadikan sebagai pendamping Buku Tematik Terpadu Kurikulum 2013. Pasti kalian sangat senang mempelajarinya dan kelak akan menjadi anak yang gemar membaca.

Agar lebih menarik, buku ini dilengkapi gambar ilustrasi yang berwarna. Kegiatan pembelajaran tersaji dalam kegiatan Persiapan, Membaca, Menanggapi, Memahami, dan Meluaskan Pemahaman. Secara umum isi buku ini yaitu:

1 Gambar PembukaTema

Berisikan ilustrasi tentang tema materi yang akan kalian pelajari.

2 Kompetensi Dasar

Menggambarkan ruang lingkup materi yang akan dibahas di dalam subtema. 


\section{Judul Subtema}

Menggambarkan subtema materi yang akan kalian pelajari

4 Gambar Pembuka Subtema

Berisikan ilustrasi tentang subtema materi yang akan kalian pelajari.

\section{Pembelajaran}

Berisikan materi membaca yang akan kalian pelajari untuk satu kali pembelajaran. Pembelajaran yang tersaji dalam buku ini menyesuaikan Buku Tematik Terpadu Kurikulum 2013 yang hanya memuat Kompetensi Dasar Bahasa Indonesia aspek keterampilan membaca, oleh karena itu buku ini hanya menyajikan pembelajaran tertentu saja.

\section{Persiapan}

Berisikan kegiatan yang mengajakmu untuk menyiapkan diri sebelum membaca. Diantaranya yaitu kegiatan tanya jawab seputar materi dan memperkirakan isi materi yang akan kalian pelajari.

\section{Membaca}

Berisikan materi bacaan yang akan kalian pelajari. Kegiatan ini untuk melatih kemampuan 
kalian dalam membaca menggunakan model yang sudah ditetapkan. Diantaranya yaitu membaca nyaring, membaca bersama-sama, membaca berpasangan, membaca terbimbing, dan membaca bebas.

8 Menanggapi

Berisikan kegiatan memberikan tanggapan setelah membaca teks materi bacaan. Kalian juga dapat berdiskusi dengan teman dan guru tentang hasil tanggapan kalian.

9 Memahami

Berisikan kegiatan untuk lebih memahami materi bacaan. Melalui kegiatan membaca ulang kalian dapat menemukan dan mempelajari kosakata baru. Berisi juga kegiatan menjawab pertanyaan seputar materibacaan.

Meluaskan Pemahaman

Berisikan kegiatan untuk meluaskan pemahaman terhadap materi bacaan. Diantaranya yaitu berisi kegiatan menuliskan kembali materi bacaan atau menceritakan ulang dengan menggunakan bahasa atau kalimat sendiri. Selain itu, juga berisi kegiatan untuk melakukan adegan bermain peran sesuai dengan materibacaan.

11 Ayo Merangkum

Berisikan bagan untuk menulis rangkuman dari materi pembelajaran. 


\section{Subtema 1}

\section{Makananku Sehat dan Bergizi}

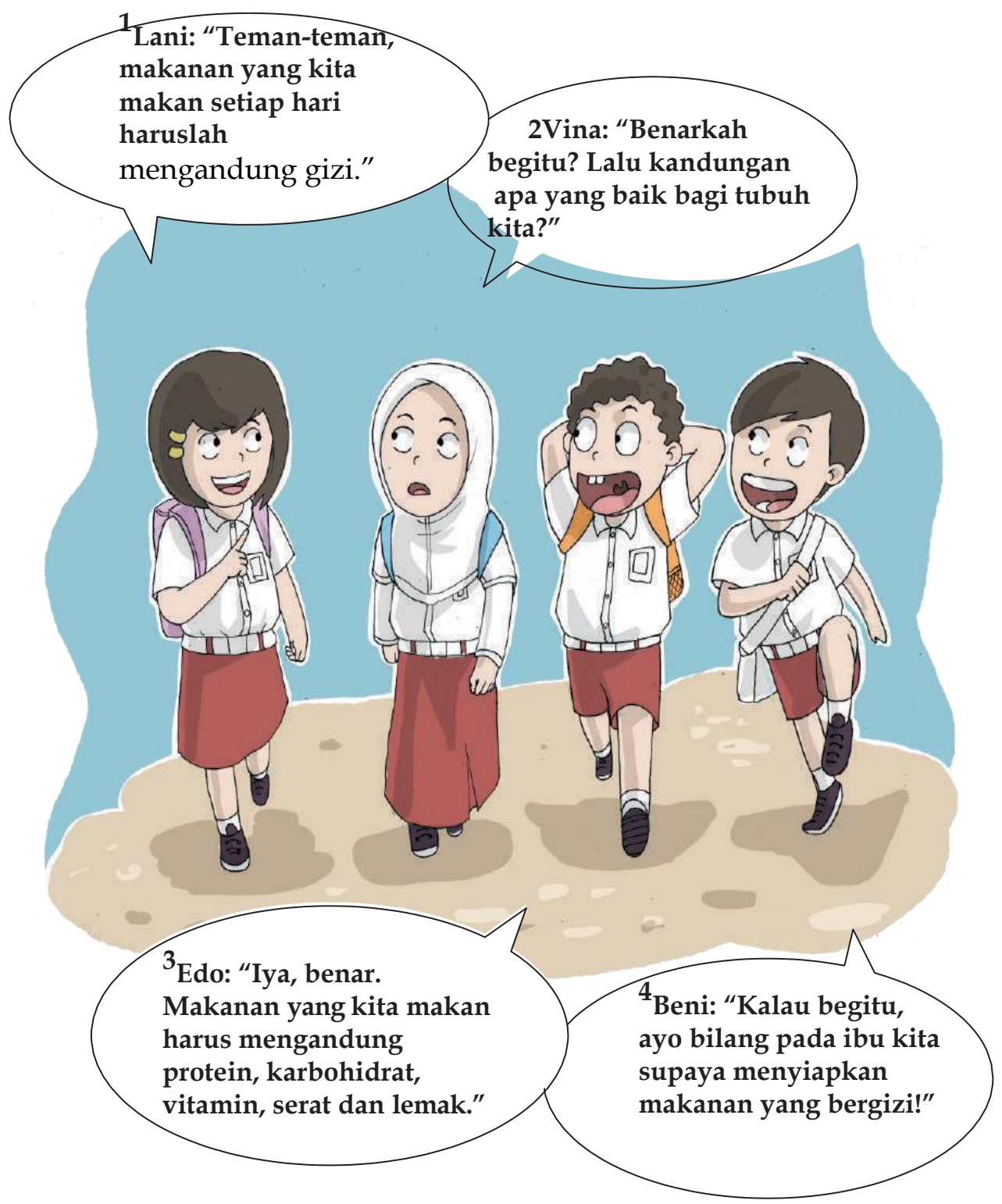




\section{Pembelajaran 1}

\section{Kompetensi Dasar}

Menggali informasi dari teks laporan hasil pengamatan tentang gaya, gerak, energi panas, bunyi, dan cahaya dengan bantuan guru dan teman dalam bahasa Indonesia lisan dan tulis dengan memilih dan memilah kosakata baku

\section{Indikator}

1. Membuat peta pikiran dari teks cerita petualangan

\section{Tujuan Pembelajaran}

1. Melalui kegiatan membaca teks cerita petualangan, peserta didik dapat membuat peta pikiran dari teks cerita tersebut dengan benar.

2. Melalui kegiatan membaca teks cerita petualangan, peserta didik dapat menceritakan kembali isi cerita tersebut dengan benar. 


\section{a. Persiapan}

Apakah selama ini kalian memakan makanan yang sehat? Apa saja makanan sehat yang biasa kamu dan temanmu makan? Nah, coba tuliskan pada kolom di bawah ini!

Tahukah kalian? Makanan sehat adalah makanan yang mengandung zat gizi seimbang. Zat gizi tersebut diperlukan oleh tubuh untuk proses pertumbuhan dan perkembangan. Makanan sehat itu mengandung karbohidrat, protein, mineral, vitamin, dan lemak tak jenuh. 


\section{b. Membaca}

Kalian sudah menuliskan makanan sehat yang biasa kamu makan. Nah, sekarang coba kalian baca cerita berikut ini! Cerita ini berisi pelajaran tentang makanan sehat. Bacalah dalam hati!

\section{Makanan Sehat Lani}

Hari ini Lani membawa makanan sehat di kotak makannya. la ingat perkataan ibu bahwa makanan sehat akan memberi energi untuknya di siang hari.

Lani berkata, "Bu, aku ingin membawa roti dan wortel kukus juga! Aku ingin punya energi yang banyak hingga siang nanti. Aku tidak ingin seperti Edo, Bu."

"Ada apa dengan Edo?" tanya ibu.

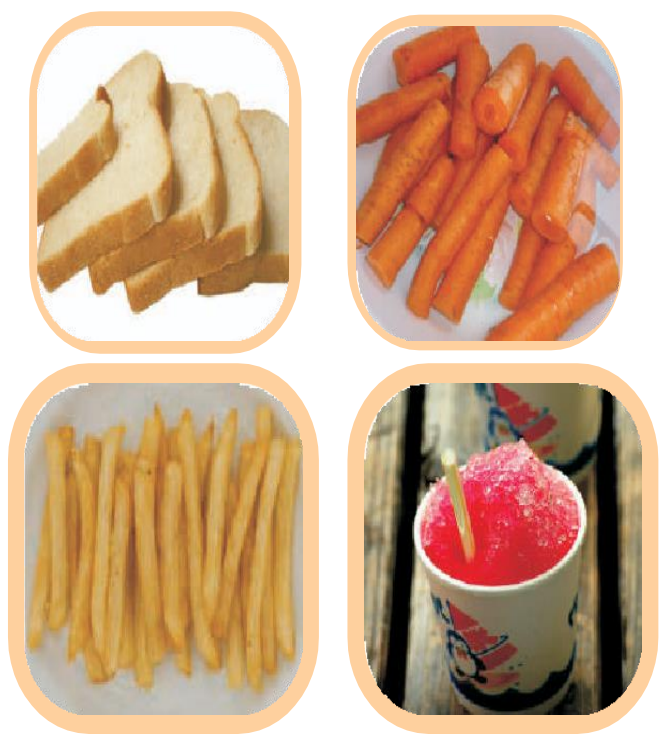

\section{Sumber: pintar2.blogspot.com, foodlibrary.org}


“Kemarin Edo membeli kentang goreng dan mi goreng instan di kantin. la tidak memakan telur rebus dan jeruk yang dibawanya dari rumah. Selain itu, Edo juga membeli permen dan es serut warna-warni!" seru Lani.

"Lalu apa yang terjadi?" tanya ibu lagi.

"Awalnya Edo merasa biasa-biasa saja. la tetap berlari- larian dan bermain bersama kami hingga waktunya masuk kelas. Tak lama Edo merasa mengantuk. la tidak tahan untuk merebahkan kepalanya di meja. Guru memanggilnya, tetapi ia tidak memperhatikan karena ia merasa lelah.

"Oh ya? Mengapa begitu, Lani?" tanya ibu lagi.

"Ternyata Edo baru tersadar bahwa makanan yang dimakan tadi mengandung banyak gula dan lemak. Jika digabungkan akan menjadi makanan yang tidak sehat. Aku sudah mengingatkan Edo bahwa kita boleh saja sesekali makan makanan seperti itu. Namun, asalkan dimakan bersama makanan sehat," lanjut Lani.

"Hebat kamu, Lani! Itulah mengapa kita harus tahu betapa pentingnya makanan sehat untuk tubuh kita. Sekarang, kita harus selalu memastikan untuk membawa makanan sehat. Makanan sehat memberi energi untuk belajar, bermain, dan melakukan hal-hal yang menyenangkan!" ujar ibu.

"Setuju, Bu! Terima kasih telah menyiapkan makanan sehat untukku setiap hari," kata Lani sambil memeluk ibunya. 


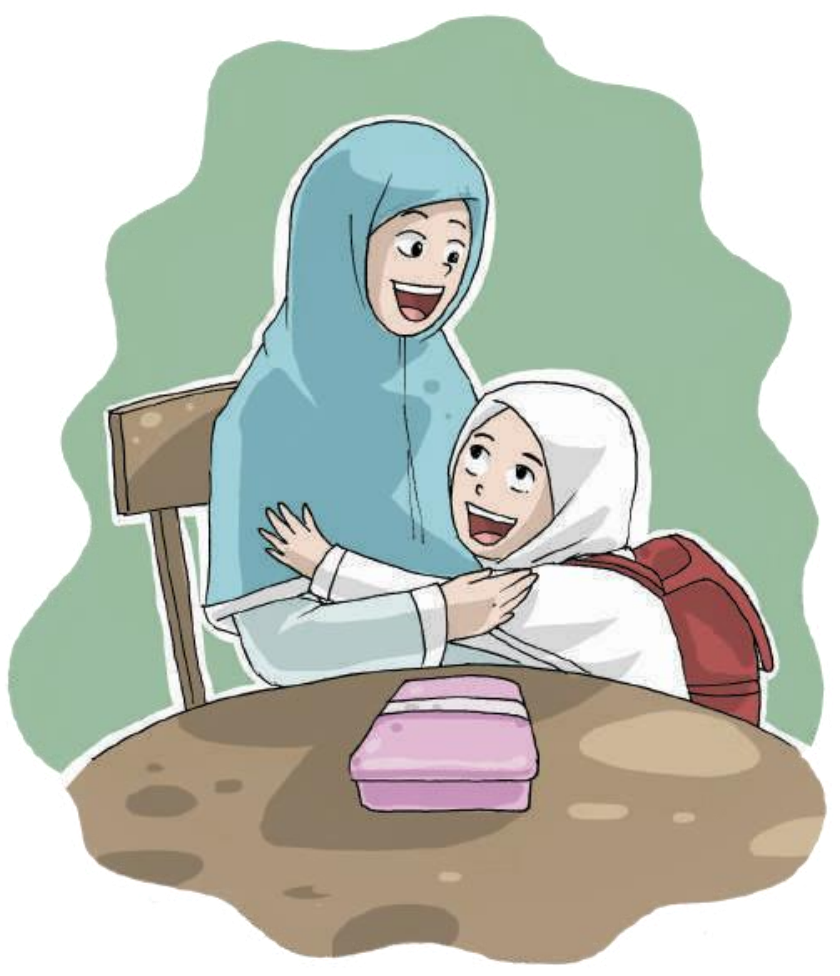

Sumber: Kemendikbud (2014: 1-2)

Buku siswa SD/ MI kelas IV tema 9 makananku sehat dan bergizi (dengan pengubahan) 


\section{c. Menanggapi}

Bagaimana cerita di atas menurut kalian, menarik bukan? Berikan tanggapan kalian tentang "Lani" dan "Edo"!

1. Berikan tanggapan kalian tentang sikap Lani terhadap makanan!

2. Berikan tanggapan kalian tentang sikap Edo terhadap makanan!

Sudah selesaikah kalian memberi tanggapan? Nah, kalau sudah sekarang diskusikan hasil tanggapan kalian itu dengan teman kelas kalian dan Bapak/lbu guru! 


\section{d. Memahamí}

Baca ulang sekali lagi cerita di atas! Temukan dan pelajari kosakata baru dengan dibimbing oleh Bapak/lbu guru!

1. energi = kekuatan,

2.

3.

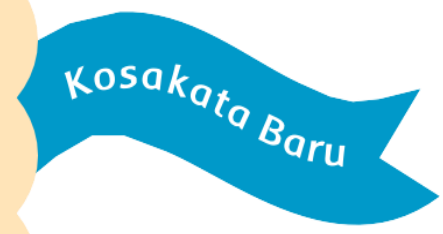

4.

Untuk lebih memahami isi bacaan kerjakan tugas berikut ini dengan teman sebangku kalian!

1. Buatlah peta pikiran tentang hal-hal penting yang kamu temukan di dalam cerita!

2. Buatlah 5 pertanyaan berdasarkan cerita "Makanan Sehat Lani"! Lalu mintalah teman kalian untuk menjawab pertanyaan-pertanyaan tersebut! 


\begin{tabular}{|c|c|c|}
\hline No. & Pertanyaan & Jawaban Teman Kalian \\
\hline 1. & & \\
\hline 2. & & \\
\hline 3. & & \\
\hline 4. & & \\
\hline 5. & & \\
\hline
\end{tabular}

9 


\section{e. Meluaskan Pemahaman}

Untuk meluaskan pemahaman kalian, ceritakan kembali isi cerita "Makanan Sehat Lani" dengan katakata kalian sendiri. Gunakan kosakata baku dan kalimat yang mudah dipahami. Berceritalah dengan berani di depan kelas!

\section{Ayo Merangkum!}

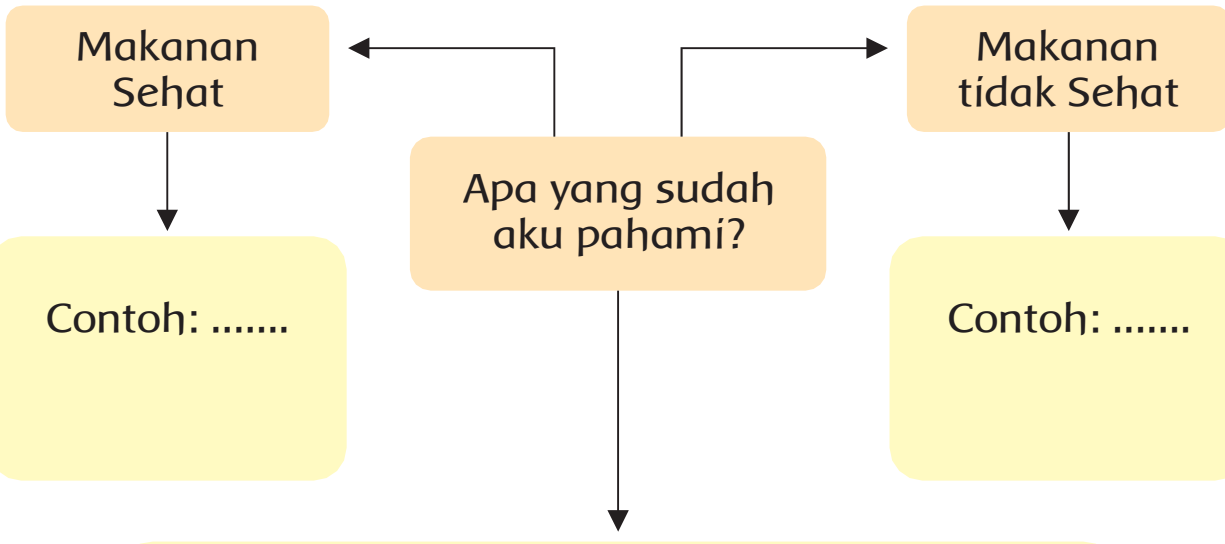

Pesan yang dapat kamu ambil dari cerita "Makanan Sehat Lani":

$1 . . . . .$.

2. ....... 


\section{Pembelajaran 2}

\section{Kompetensi Dasar}

3.1 Menggali informasi dari teks laporan hasil pengamatan tentang gaya, gerak, energi panas, bunyi, dan cahaya dengan bantuan guru dan teman dalam bahasa Indonesia lisan dan tulis dengan memilih dan memilah kosa kata baku.

\section{Indikator}

1. Menemukan informasi dari teks laporan tentang pengolahan sumber daya alam yang digunakan.

\section{Tujuan Pembelajaran}

1. Melalui kegiatan membaca teks cerita ikan, peserta didik dapat menemukan informasi tentang pengolahan sumber daya alam yang digunakan dengan benar.

2. Melalui kegiatan membaca teks cerita ikan, peserta didik dapat menjelaskan kembali isi teks tersebut dengan menggunakan kosakata baku. 